\title{
Preparation of a new solid acid and its catalytic performance in di(1-naphthyl)methane hydrocracking
}

\author{
Meixia Zhao, Xianyong Wei*, Zhimin Zong \\ Key Laboratory of Coal Processing and Efficient Utilization, Ministry of Education, China University of Mining \& Technology, Xuzhou 221116, Jiangsu, \\ China
}

A R T I C L E I N F 0

Article history:

Received 3 March 2016

Accepted 15 April 2016

Published 5 August 2016

\section{Keywords:}

Solid acid

Di(1-naphthyl)methane

Hydrocracking

$\mathrm{H}^{+}$transfer

\begin{abstract}
A B S T R A C T
A new solid acid was prepared by trifluoromethanesulfonic acid (TFMSA) impregnation into an acid-treated attapulgite (ATA). Di(1-naphthyl)methane (DNM) hydrocracking was used as the probe reaction to evaluate the catalytic performance of TFMSA/ATA for cleaving $\mathrm{C}_{\mathrm{ar}}-\mathrm{C}_{\text {alk }}$ bridged bonds in coals. The results show that DNM was specifically hydrocracked to naphthalene and 1-methylnaphthalene over TFMSA/ATA in methanol in the absence of gaseous hydrogen. In particular, TFMSA/ATA was demonstrated to be stable after four cycles with slight loss in catalytic activity. Furthermore, a proposed $\mathrm{H}^{+}$transfer mechanism successfully interprets the TFMSA/ATA- catalyzed hydrocracking reaction of DNM.
\end{abstract}

(C) 2016, Dalian Institute of Chemical Physics, Chinese Academy of Sciences. Published by Elsevier B.V. All rights reserved.

gating coal-related model compound (CRMC) reactions proved to be a powerful approach for revealing molecular-level DCL mechanisms [11-13]. In recent years, significant efforts have been devoted to directional degradation of coals and CRMCs over solid acids. Wang et al. [14] investigated the decomposition of diphenylmethane and bibenzyl over sulfated zirconia. The work suggested that the acidic property of the catalyst contributed largely to CRMC bond rupture. Yue et al. [15] examined the hydrocracking of di(1-naphthyl)methane (DNM) over a solid acid prepared by pentachloroantimony and trimethylsilyl trifluoromethanesulfonate impregnation into an activated carbon. The results showed that heterolytic cleavage of $\mathrm{H}_{2}$ into $\mathrm{H}^{+}$and $\mathrm{H}^{-}$was the key step for the cleavage of $\mathrm{C}_{a}-\mathrm{C}_{\text {alk }}$ bond in DNM. The aforementioned solid acids, although effective, still require the use of pressurized hydrogen at elevated temperatures. Therefore, it is imperative to develop nov-

\footnotetext{
* Corresponding author. Tel: +86-516-83885951; Fax: +86-516-83884399; E-mail: wei_xianyong@163.com This work was supported by the Fundamental Research Fund for the Central Universities (China University of Mining \& Technology, 2014ZDPY34) and the Priority Academic Program Development of Jiangsu Higher Education Institutions.
} 
el catalysts that allow cleaving the bridged bonds in coals under mild conditions, especially in the absence of pressurized hydrogen.

Catalyst supports play vital roles in improving catalytic activity and stability. Attapulgite is a type of hydrated magnesium aluminum silicate having lath or fibrous morphology, being desirable as a solid acid catalyst support because of its large specific surface area, considerable porosity, and excellent thermal stability [16].

In this study, a new solid acid was prepared using an acid-treated attapulgite (ATA) as the support and TFMSA as the active component. The catalytic performance of as-prepared TFMSA/ATA was investigated by cleaving $\mathrm{C}_{\mathrm{ar}}-\mathrm{C}_{\text {alk }}$ bond in DNM in the absence of $\mathrm{H}_{2}$. The potential cleavage route of DNM over TFMSA/ATA was also deduced.

\section{Experimental}

\subsection{Materials}

Attapulgite powder (AP) was purchased from Jiangsu Huahong Mining Chemical Co., Ltd., Xuyi, China. DNM is an analytical reagent purchased from Heowns Chemical Co., Ltd., Tianjin, China. Both methanol and TFMSA were purchased from Aladdin Industrial Inc., Shanghai, China. Methanol was purified by distillation prior to use.

\subsection{Catalyst preparation}

AP was treated in $0.5 \mathrm{~mol} / \mathrm{L} \mathrm{HCl}$ aqueous solution under reflux with vigorous agitation for $4 \mathrm{~h}$. Thereafter, the suspension was filtered and washed with distilled water until $\mathrm{Cl}^{-}$was undetectable by silver nitrate titration. The filter cake was dried under vacuum at $110{ }^{\circ} \mathrm{C}$ for $6 \mathrm{~h}$ to obtain ATA, which was then ground and sieved to 100-200 mesh size. TFMSA/ATA was prepared by impregnation, i.e., TFMSA (5 mL) was added dropwise into ATA ( $2 \mathrm{~g}$ ) under a $\mathrm{N}_{2}$ atmosphere followed by refluxing at $90{ }^{\circ} \mathrm{C}$ for $8 \mathrm{~h}$. The mixture was cooled, filtered, washed with acetone, and calcined at $350{ }^{\circ} \mathrm{C}$ for $12 \mathrm{~h}$. TFMSA loaded on ATA is ca. $14.7 \%$, which was calculated according to the mass change. Besides TFMSA/ATA, TFMSA $/ \gamma-\mathrm{Al}_{2} \mathrm{O}_{3}$ and TFMSA/ZSM-5 were also prepared under the same conditions.

\subsection{Catalyst characterization}

Transmission electron microscopic (TEM) observation of ATA and TFMSA/ATA and corresponding elemental analysis were performed using a JEM-1011 JEOL microscope operating at $200 \mathrm{kV}$ coupled to an energy-dispersive spectrometric detector. Fourier transform infrared (FTIR) analysis was performed using a Nicolet Magna IR-560 spectrometer with a resolution of $4 \mathrm{~cm}^{-1}$ over the spectral range of 4000-400 $\mathrm{cm}^{-1}$ using $\mathrm{KBr}$ pellets. X-ray diffraction (XRD) patterns were recorded on a Bruker D8 Advance diffractometer with $\mathrm{Cu} K_{\alpha}$ radiation $(\lambda=1.5406 \AA)$ at $40 \mathrm{kV}$ and $30 \mathrm{~mA}$ in the $2 \theta$ range of $3^{\circ}-80^{\circ}$. Specific surface area, pore volume, and average pore size of the samples were measured using an Autosorb-1-MP apparatus at $-196{ }^{\circ} \mathrm{C}$. Samples were previously outgassed at $300{ }^{\circ} \mathrm{C}$ for $5 \mathrm{~h}$. $\mathrm{NH}_{3}$ temperature-programmed desorption ( $\mathrm{NH}_{3}$-TPD) was conducted on a TP-5000 type multi-function adsorption instrument. The samples were pretreated at $650{ }^{\circ} \mathrm{C}$ for $1 \mathrm{~h}$ and then cooled to $100{ }^{\circ} \mathrm{C}$. The introduction of $\mathrm{NH}_{3}$ was performed for $0.5 \mathrm{~h}$ followed by purification with He for $1 \mathrm{~h}$ to remove physisorbed $\mathrm{NH}_{3}$. Desorption under He was performed in the range of $100-800{ }^{\circ} \mathrm{C}$ at $10{ }^{\circ} \mathrm{C} / \mathrm{min}$ to remove chemisorbed $\mathrm{NH}_{3}$. X-ray photoelectron spectroscopic (XPS) measurements were determined using a Thermo Fisher ESCALAB $250 \mathrm{Xi}$ spectrophotometer with the $\mathrm{Al} K_{\alpha}$ radiation with a beam spot size of $900 \mu \mathrm{m}$ (energy step size $1.000 \mathrm{eV}$, pass energy $50.0 \mathrm{eV}$ ). Accurate binding energies were determined by reference to the $\mathrm{C} 1 \mathrm{~s}$ peak at $284.5 \mathrm{eV}$.

\subsection{Catalytic reactions}

DNM (1 mmol), catalyst (0-40 mg), and methanol (10 mL) were added into a $60-\mathrm{mL}$ stainless steel and magnetically stirred autoclave. The autoclave was purged with $\mathrm{N}_{2}$ and pressurized to $1 \mathrm{MPa}$ at room temperature before heating to a desired temperature $\left(260-320^{\circ} \mathrm{C}\right)$. After reaction at a specific temperature for a prescribed period of time $(0.5-5 \mathrm{~h})$, the autoclave was immediately quenched to room temperature in an ice-water bath before filtering the reaction mixture. The filtrate was analyzed using an Agilent 7890/5975 gas chromatograph/mass spectrometer (GC/MS) equipped with a capillary column coated with HP-5MS (60 $\mathrm{m} \times 0.25 \mathrm{~mm} \times 0.25 \mu \mathrm{m})$ and a quadrupole analyzer operated in electron impact $(70 \mathrm{eV})$ mode. The capillary column was heated from 60 to $300{ }^{\circ} \mathrm{C}$ at 10 ${ }^{\circ} \mathrm{C} / \mathrm{min}$ and held at $300{ }^{\circ} \mathrm{C}$ for $6 \mathrm{~min}$. The relative content of each compound was determined by normalizing peak area, i.e., the peak area of the compound divided by the sum of the peak areas of all the identified compounds in the total ion chromatogram. Quantitative analysis was performed using DNM as an external standard during analysis with GC/MS. Furthermore, each experiment, under the same conditions, was repeated at least three times to minimize DNM conversion and product yield errors to less than $\pm 1 \%$.

\section{Results and discussion}

As Fig. 1 shows, ATA exhibits ordered fibrous morphology and a smooth surface with diameters between 20 and $30 \mathrm{~nm}$. Conversely, the surface characteristics of TFMSA/ATA differ from ATA in which a rough surface is observed. Another different surface feature is the presence of irregular grains with diameters $<10 \mathrm{~nm}$ that are relatively uniformly distributed on the ATA surface without obvious aggregation. Among the detected elements, $\mathrm{O}, \mathrm{Mg}, \mathrm{Al}$, and $\mathrm{Si}$ are mainly attributed to the ATA framework, while $\mathrm{K}$ and Fe most likely arise from impurities in the parent ATA. Additionally, F and S from TFMSA were also detected in TFMSA/ATA (Fig. 2). Energy-dispersive spectrometric (EDS) analysis demonstrates a F content of $5.2 \mathrm{wt} \%$ on TFMSA/ATA, which is close to the F loading (5.6\%) calculated according to the mass difference between added ATA and the resulting TFMSA/ATA. 


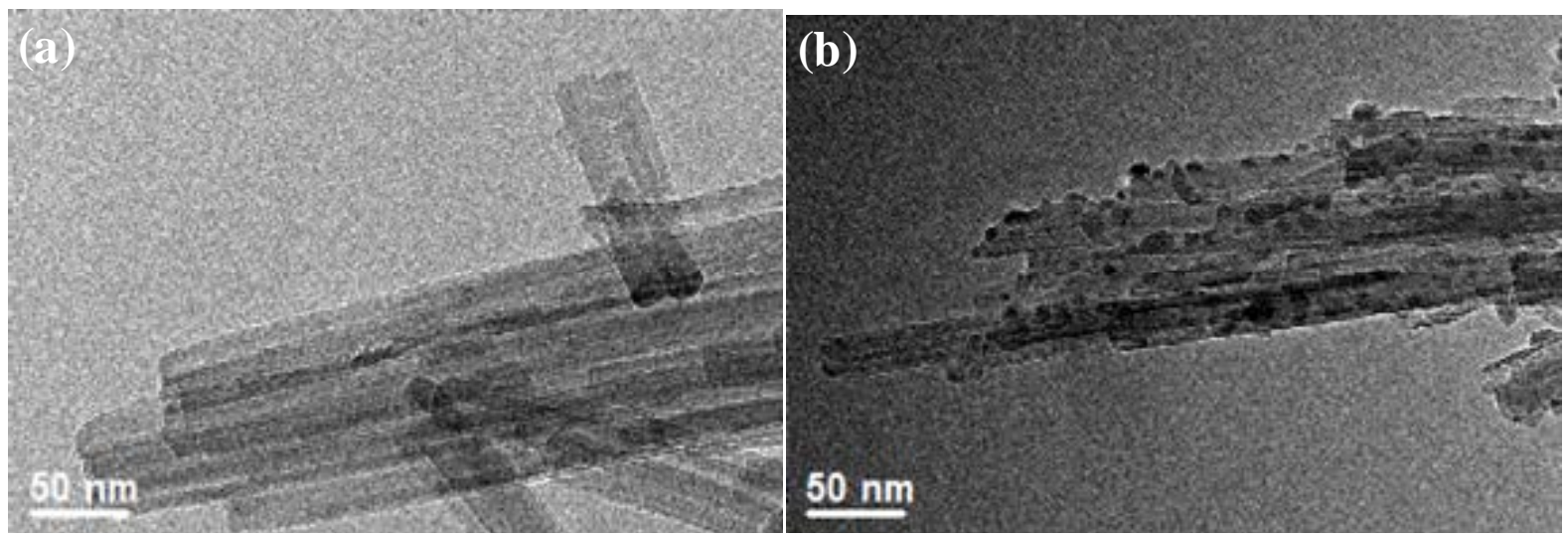

Fig. 1. TEM images of ATA (a) and TFMSA/ATA (b).

As Fig. 3 illustrates, there are significant differences in FTIR spectra among AP, ATA, and TFMSA/ATA. The absorbance at $3616 \mathrm{~cm}^{-1}$ is ascribed to the $-\mathrm{OH}$ stretching vibration in dioctahedral coordination, while the band at $3550 \mathrm{~cm}^{-1}$ is attributed to the $-\mathrm{OH}$ stretching vibration of adsorbed water coordinated to $\mathrm{Al}$ and $\mathrm{Mg}$ at the edges of the channels [17]. The band at $1630 \mathrm{~cm}^{-1}$ results from the bending vibration of zeolitic water [18]. The characteristic absorbances at 1015 and $801 \mathrm{~cm}^{-1}$ are assigned to $\mathrm{Si}-\mathrm{OR}$ and $\mathrm{Si}-\mathrm{O}-\mathrm{Si}$ bonds, respectively [19]. Noteworthily, the absorbance of carbonates at $1451 \mathrm{~cm}^{-1}$ from ATA and TFMSA/ATA is much weaker than that from AP, indicating that the majority of carbonates in AP were removed by acid treatment. The FTIR spectrum of TFMSA/ATA displays additional bands at 1255 and 1173, 1035, and $614 \mathrm{~cm}^{-1}$, which correspond to symmetric and asymmetric stretching vibrations of the $\mathrm{S}=\mathrm{O}$ bond, $\mathrm{C}-\mathrm{F}$ stretching vibrations, and $\mathrm{C}-\mathrm{S}$ bending vibrations, respectively [20]. These results evidently indicate that TFMSA was successfully loaded on ATA.

As Fig. 4 exhibits, the existence of $\mathrm{C}, \mathrm{F}, \mathrm{S}$, and $\mathrm{O}$ along with other elements in TFMSA/ATA is further verified by XPS analy-

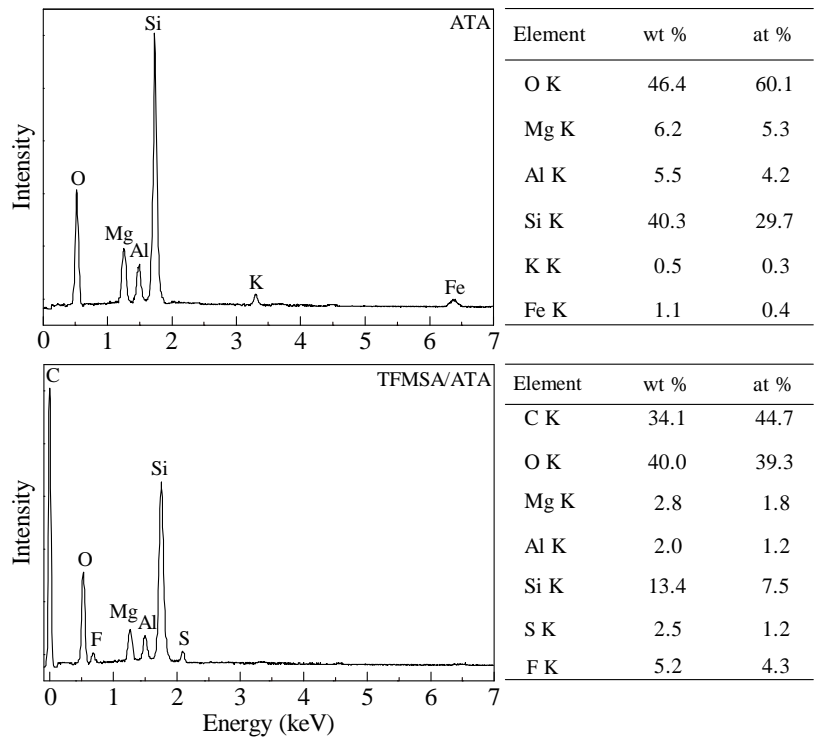

Fig. 2. Energy dispersive spectra of ATA and TFMSA/ATA. sis. The atomic density of $\mathrm{F}$ is ca. $4.40 \%$ on the surface of TFMSA/ATA (Table 1), which is consistent with EDS analysis (Fig. 2). The F $1 s$ spectrum of TFMSA/ATA is fitted with four distinct peaks related to the various bonding configurations of $\mathrm{F}$ atoms in TFMSA/ATA. Specifically, the strong peak located at $687.8 \mathrm{eV}$ is assigned to the $\mathrm{F}-\mathrm{Al}$ bond [21]. The peak at 688.8 $\mathrm{eV}$ is attributed to the $\mathrm{F}-\mathrm{C}$ bond [22], while the peaks centered at 685.1 and $686.8 \mathrm{eV}$ result from F-Mg and F-Si bonds [23,24], respectively. These results are indicative of the interaction between ATA and supported TFMSA.

As Fig. 5 demonstrates, there are appreciable differences in the XRD patterns among AP, ATA, and TFMSA/ATA. The peaks at $8.5^{\circ}, 16.9^{\circ}$, and $33.6^{\circ}$ can be ascribed to the characteristic diffraction peaks of AP, representing the (110), (040), and (400) planes, respectively, while those at $13.7^{\circ}, 20.0^{\circ}$, and $21.1^{\circ}$ can be attributed to the Si-O-Si crystalline layers in AP $[25,26]$. The peak at $24.6^{\circ}$ can be indexed to the diffraction from quartz as an impurity [27] and its intensity from ATA is much weaker than that from AP, further indicating that the impurity was effectively removed by acid treatment. Compared with ATA, the diffraction peaks of TFMSA/ATA at $8.5^{\circ}, 16.9^{\circ}$, and $33.6^{\circ}$ are weak or broad, implying that the crystalline structure was significantly destroyed by TFMSA loading.

Only a single desorption peak at $358.3{ }^{\circ} \mathrm{C}$ was observed in the $\mathrm{NH}_{3}$-TPD profile of ATA (Fig. 6), which can be assigned to the desorption of $\mathrm{NH}_{3}$ from medium-strength Lewis acid sites on ATA [28]. Compared with ATA, TFMSA/ATA displays two

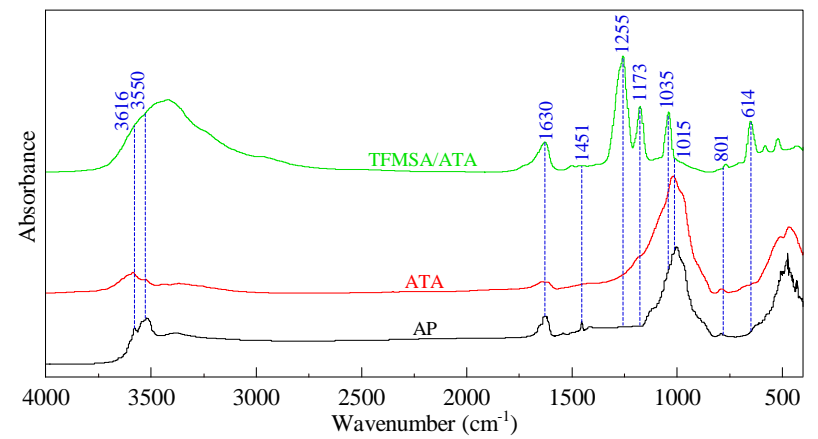

Fig. 3. FTIR spectra of AP, ATA, and TFMSA/ATA. 

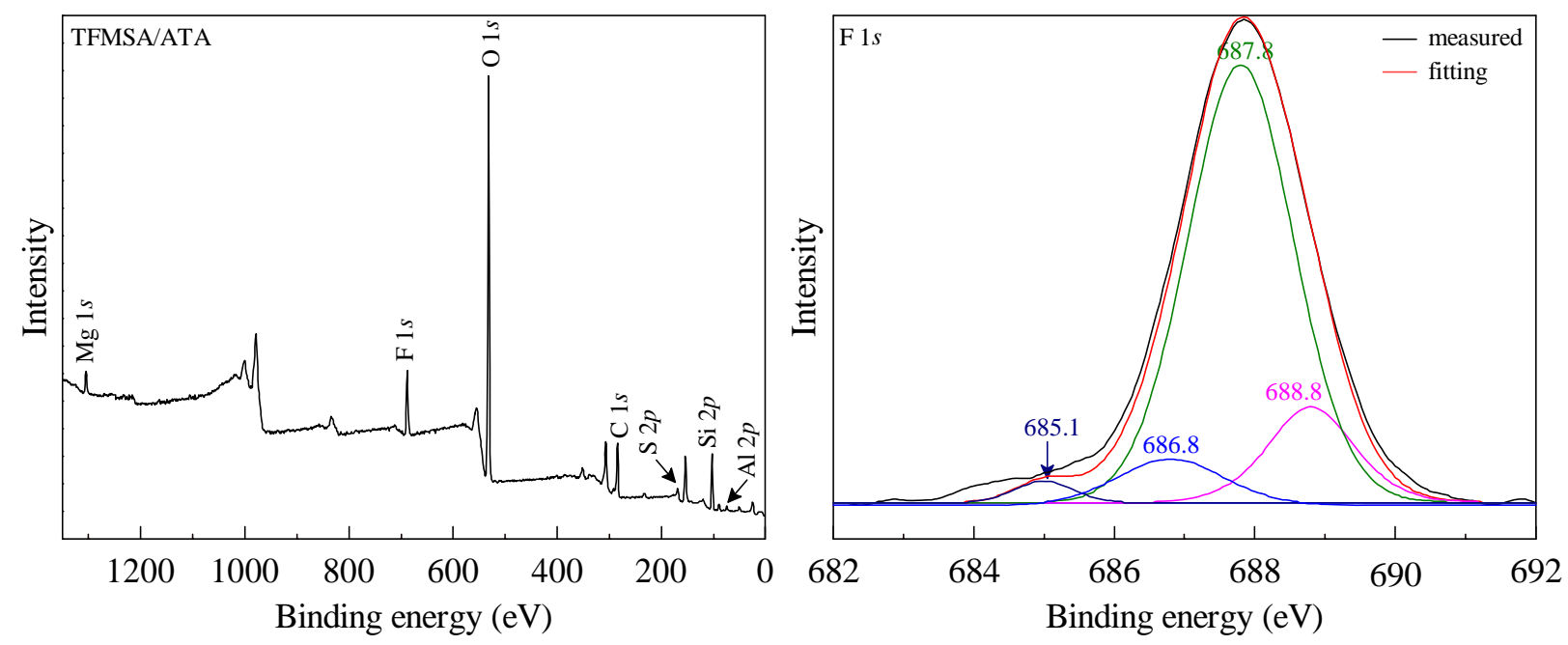

Fig. 4. XPS spectra of TFMSA/ATA.

Table 1

Atomic densities of main elements on the surface of TFMSA/ATA.

\begin{tabular}{lcc}
\hline Element & Binding energy (eV) & Atomic density (\%) \\
\hline Al $2 p$ & 74.04 & 1.13 \\
Si $2 p$ & 102.70 & 7.62 \\
S $2 p$ & 168.55 & 1.31 \\
$\mathrm{Cl} s$ & 284.17 & 44.11 \\
$\mathrm{O} 1 s$ & 531.94 & 39.67 \\
$\mathrm{~F} 1 s$ & 687.86 & 4.40 \\
$\mathrm{Mg} 1 s$ & 1304.82 & 1.76 \\
\hline
\end{tabular}

desorption peaks at 245.1 and $615.2{ }^{\circ} \mathrm{C}$, indicating the presence of weak and strong acid sites on TFMSA/ATA, respectively. Much stronger acid sites created after supporting TFMSA are tentatively attributed to the interaction of supported TFMSA with ATA, which is responsible for donating $\mathrm{H}^{+}$.

Table 2 shows that the specific surface area $\left(278 \mathrm{~m}^{2} / \mathrm{g}\right)$ of ATA is significantly larger than that $\left(169 \mathrm{~m}^{2} / \mathrm{g}\right)$ of AP, favoring the subsequent TFMSA loading. The decrease in specific surface area and increase in pore size for ATA after TFMSA loading imply that the majority of TFMSA was anchored to the channels of ATA, expanding the pore size to some extent.

As Fig. 7 exhibits, only naphthalene and 1-methylnaphtha-

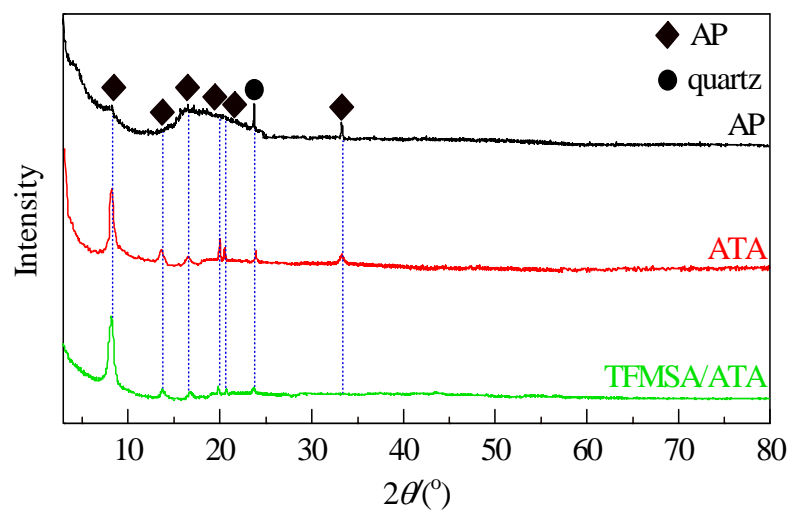

Fig. 5. XRD patterns of AP, ATA, and TFMSA/ATA. lene were detected in the mixtures from DNM hydrocracking, while the resulting formaldehyde from methanol dehydrogenation cannot be detected as it was drawn out together with the solvent during analysis with GC/MS. The results show that both DNM conversion and product yields increase with raising temperature, increasing TFMSA/ATA feed, and prolonging time; however, DNM conversion almost reached $100 \%$ at $300{ }^{\circ} \mathrm{C}$ over $40 \mathrm{mg}$ TFMSA/ATA for $3 \mathrm{~h}$. Interestingly, the yield of naphthalene is significantly higher than that of 1-methylnaphthalene, indicating significant demethylation of 1-methylnaphthalene. The difference in naphthalene and 1-methylnaphthalene yields also increases with raising temperature, increasing TFMSA/ATA feed, and prolonging time. The data suggest that TFMSA/ATA selectively catalyzes DNM hydrocracking and demethylation of the resulting 1-methylnaphthalene. The activity of TFMSA/ATA for DNM hydrocracking is significantly higher

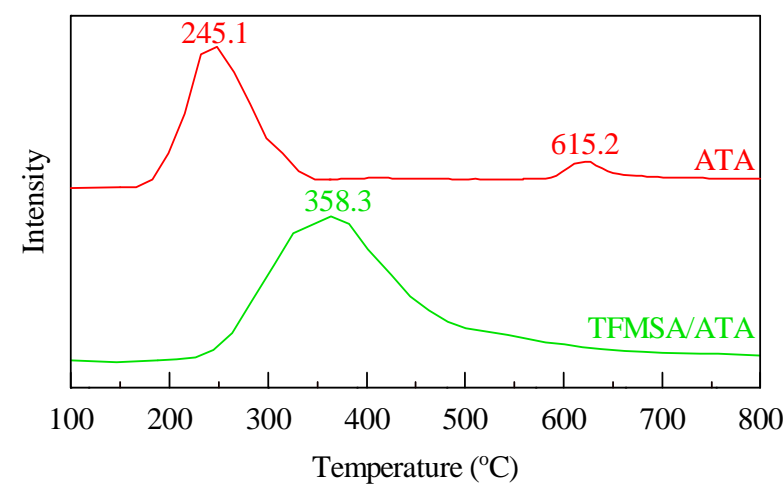

Fig. 6. $\mathrm{NH}_{3}$-TPD profiles of ATA and TFMSA/ATA.

Table 2

Physicochemical properties of AP, ATA, and TFMSA/ATA.

\begin{tabular}{lccc}
\hline Sample & $\begin{array}{c}\text { Specific surface area } \\
\left(\mathrm{m}^{2} / \mathrm{g}\right)\end{array}$ & $\begin{array}{c}\text { Pore volume } \\
\left(\mathrm{cm}^{3} / \mathrm{g}\right)\end{array}$ & $\begin{array}{c}\text { Average pore size } \\
(\mathrm{nm})\end{array}$ \\
\hline AP & 169 & 0.29 & 4.60 \\
ATA & 278 & 0.50 & 7.55 \\
TFMSA/ATA & 156 & 0.27 & 7.92 \\
\hline
\end{tabular}



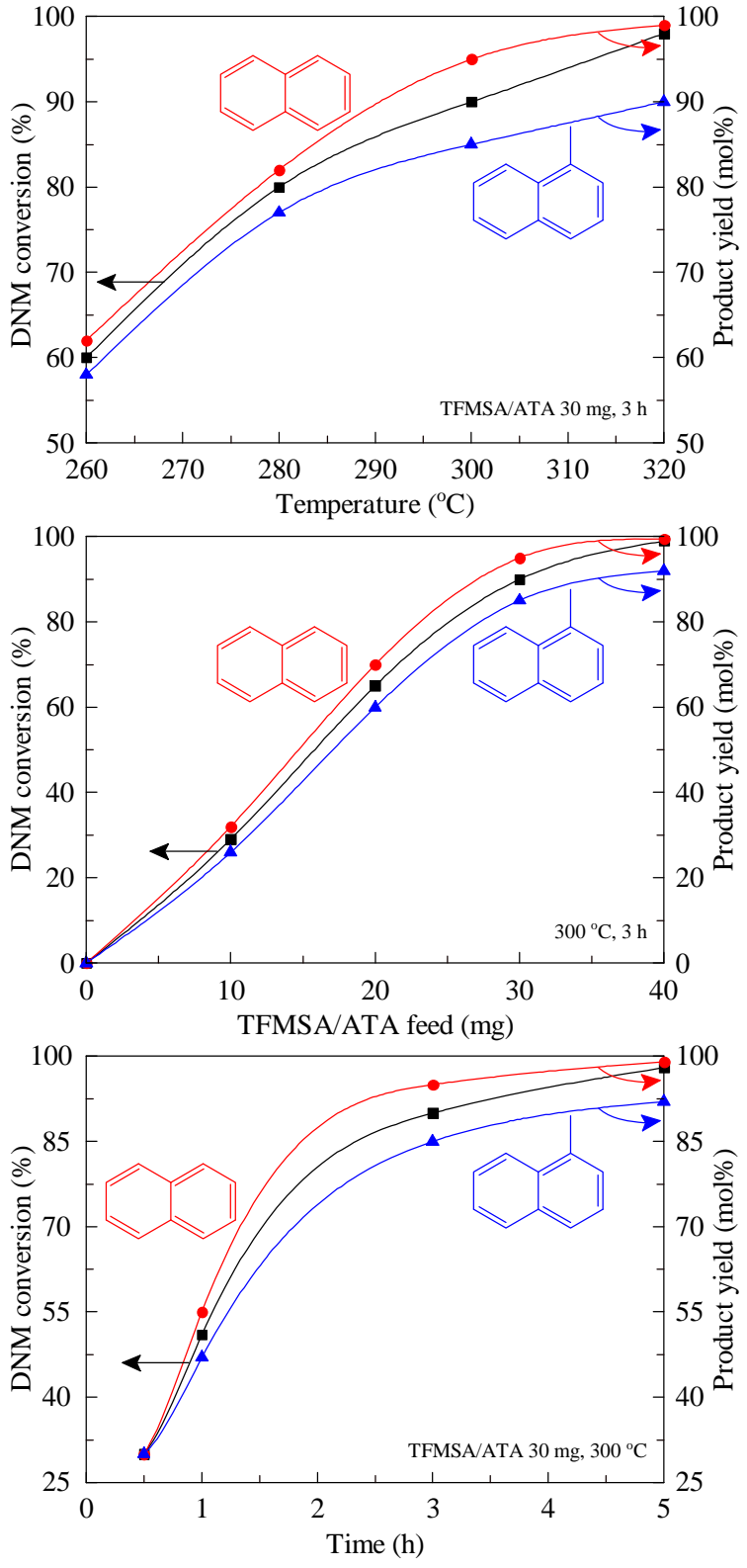

Fig. 7. Effects of temperature, TFMSA/ATA feed, and time on DNM hydrocracking.

than that of either TFMSA $/ \gamma-\mathrm{Al}_{2} \mathrm{O}_{3}$ or TFMSA/ZSM- 5 under the same conditions (Fig. 8). The outstanding catalytic performance displayed by TFMSA/ATA is not only attributed to its large specific surface area but is also related to the synergic effect between ATA and the supported TFMSA.

The dissociation energy of $\mathrm{Car}_{\text {allk }}$ bond in DNM was reported to be $355.6 \mathrm{~kJ} / \mathrm{mol}$, therefore thermal cleavage of the $\mathrm{Car}_{\mathrm{ar}} \mathrm{C}_{\mathrm{alk}}$ bond in DNM at $300{ }^{\circ} \mathrm{C}$ is extremely difficult [29]. Hydrogen transfer either from $\mathrm{H}^{\bullet}$ or $\mathrm{H}^{+}$greatly facilitates $\mathrm{Car}-\mathrm{Calk}^{-}$ bond cleavage, as the attack of $\mathrm{H}^{\cdot}$ or $\mathrm{H}^{+}$on the ipso-position of an aromatic ring connected to methylene yields a stable arene rather than a labile aryl radical in addition to a relatively stable leaving group, i.e., an arylmethyl radical or arylmethylium $[30,31]$. Analysis of TFMSA/ATA suggests that the interaction

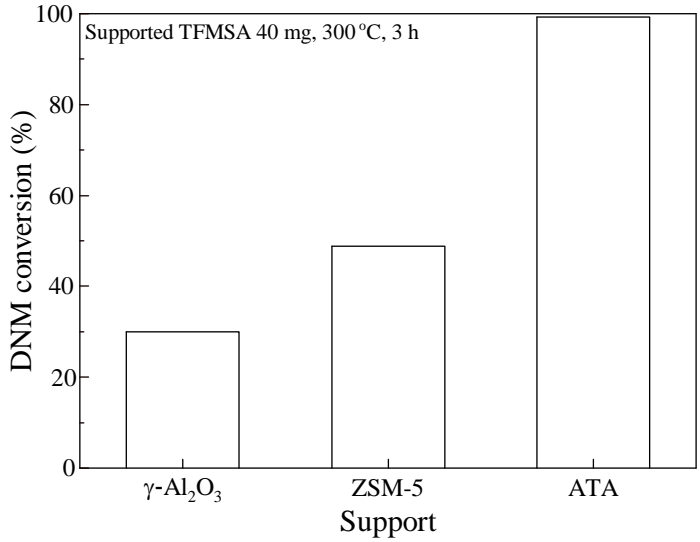

Fig. 8. DNM conversion over different supported TFMSA.

between ATA and supported TFMSA favors the release of $\mathrm{H}^{+}$ from TFMSA/ATA. The attack of $\mathrm{H}^{+}$from TFMSA/ATA on the ipso-position of DNM leads to the formation of naphthalene and naphth-1-ylmethylium, as demonstrated in Scheme 1. Subsequently, $\mathrm{H}^{-}$abstraction from methanol by the resulting naphth-1-ylmethylium proceeds, resulting in 1-methylnaphthalene and formaldehyde along with the release of $\mathrm{H}^{+}$. The released $\mathrm{H}^{+}$subsequently induces DNM hydrocracking or 1-methylnaphthalene demethylation.

Commercial viability requires excellent catalyst stability, therefore catalytic recycling tests conducted on TFMSA/ATA were performed. As exhibited in Fig. 9, DNM conversion slightly decreases with increasing recycle times, indicating good stability of the catalyst. The slight decrease of DNM conversion may be related to carbon deposition. The $\mathrm{NH}_{3}$-TPD profile of the recycled TFMSA/ATA catalyst suggests that there is no appreciable loss in acidity for the spent catalyst. The above evidence indicates that TFMSA/ATA presents excellent stability.
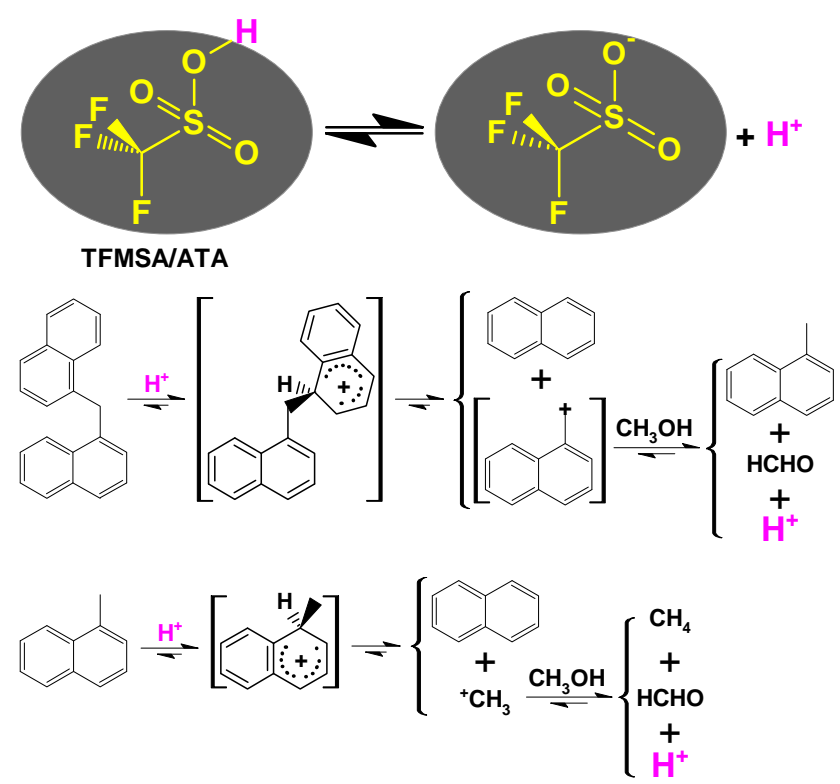

Scheme 1. Possible mechanism for DNM hydrocracking over TFMSA/ATA. 

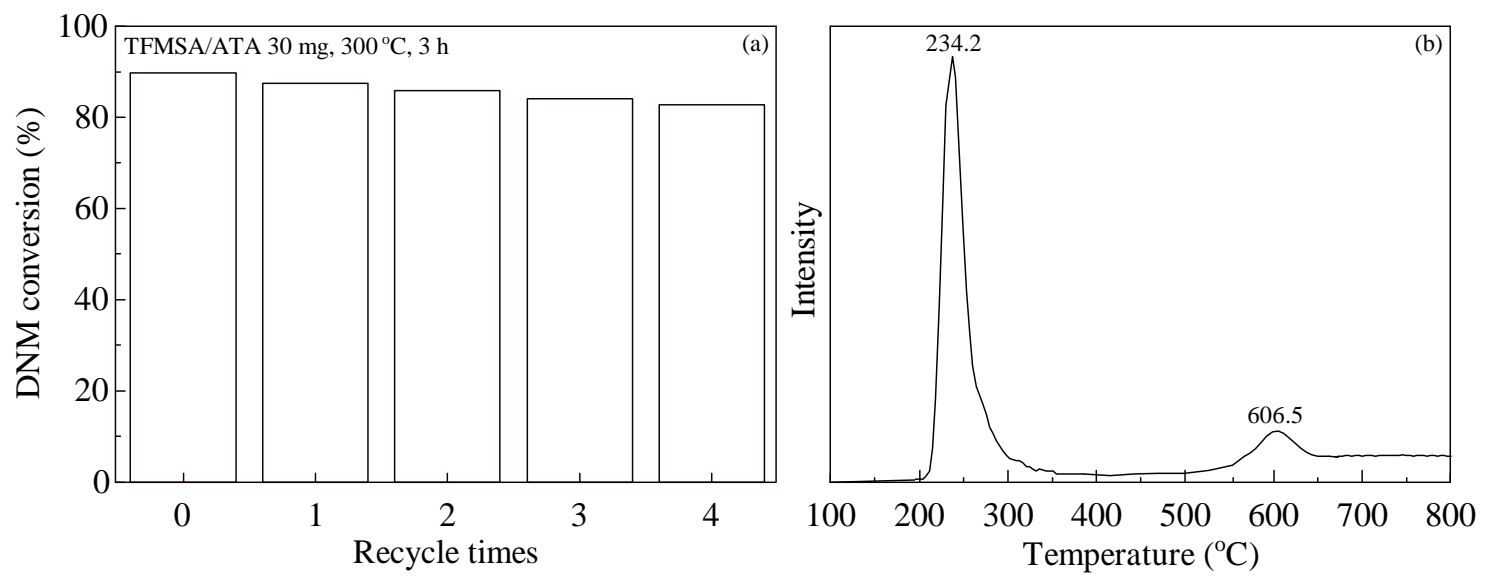

Fig. 9. DNM conversion over fresh and recycled TFMSA/ATA (a) and $\mathrm{NH}_{3}$-TPD profile of TFMSA/ATA after 4-times of recycles (b).

\section{Conclusions}

Near $100 \%$ hydrocracking of DNM to naphthalene and 1-methylnaphthalene over TFMSA/ATA at $300{ }^{\circ} \mathrm{C}$ in methanol in the absence of gaseous hydrogen was observed, suggesting that TFMSA/ATA exhibits excellent catalytic activity for the cleavage of $\mathrm{Car}_{\mathrm{r}}-\mathrm{C}_{\text {alk }}$ bridged bonds under mild conditions. The catalytic mechanism of DNM hydrocracking over TFMSA/ATA is ascribed to the preference of the catalyst to promote $\mathrm{H}^{+}$ transfer to the ipso-position of DNM. No obvious deactivation was observed even after several cycles. The TFMSA/ATA catalyst provides a promising new route for preparing similar catalysts applied in coal conversions.

\section{References}

[1] S. Vasireddy, B. Morreale, A. Cugini, C. Song, J. J. Spivey, Energy Environ. Sci., 2011, 4, 311-345.

[2] I. Mochida, O. Okuma, S. H. Yoon, Chem. Rev., 2014, 114, 1637-1672.

[3] F. Haghighat, A. de Klerk, Energy Fuels, 2014, 28, 1012-1019.

[4] Y. Z. Li, F. Y. Ma, X. T. Su, C. Sun, J. C. Liu, Z. Q. Sun, Y. L. Hou, Catal. Commun., 2012, 26, 231-234.

[5] X. M. Yue, X. Y. Wei, B. Sun, Y. H. Wang, Z. M. Zong, Z. W. Liu, Int. J.
Min. Sci. Technol., 2012, 22, 251-254.

[6] M. Trautmann, S. Lang, Y. Traa, Fuel, 2015, 151, 102-109.

[7] K. Shimizu, H. Karamatsu, A. Inaba, A. Suganuma, I. Saito, Fuel, 1995, 74, 853-859.

[8] K. Shimizu, K. Miki, I. Saitou, Fuel, 1997, 76, 23-27.

[9] G. A. Olah, M. R. Bruce, E. H. Edelson, A. Husain, Fuel, 1984, 63, 1130-1137.

[10] M. Nomura, T. Muratani, Y. Tajima, S. Murata, Fuel Process. Technol., 1995, 43, 213-225.

[11] Z. H. Ni, Z. M. Zong, L. F. Zhang, L. B. Sun, Y. Liu, X. H. Yuan, X. Y. Wei, Energy Fuels, 2003, 17, 60-61.

[12] L. B. Sun, Z. M. Zong, J. H. Kou, G. F. Liu, X. Sun, X. Y. Wei, G. J. Zhou, C. W. Lee, Energy Fuels, 2005, 19, 1-6.

[13] M. X. Zhao, X. Y. Wei, M. Qu, Z. K. Li, J. Liu, J. Kong, D. D. Zhang, H. L. Yan, Z. M. Zong, Fuel Process. Technol., 2016, 142, 258-263.

[14] Z. C. Wang, Z. S. Wang, H. F. Shui, Z. P. Lei, S. B. Ren, S. G. Kang, Y. N. Zhu, Fuel, 2010, 89, 2477-2482.

[15] X. M. Yue, X. Y. Wei, B. Sun, Y. H. Wang, Z. M. Zong, X. Fan, Z. W. Liu, Appl. Catal. A, 2012, 425-426, 79-84.

[16] C. Z. Zhu, X. H. Wang, Q. Huang, L. Huang, J. J. Xie, C. S. Qing, T. H. Chen, Chem. Eng. J., 2013, 225, 567-573.

[17] H. M. Yang, A. D. Tang, J. Ouyang, M. Li, S. Mann, J. Phys. Chem. B, 2010, 114, 2390-2398.

[18] L. X. Zhang, Q. Z. Jin, L. Shan, Y. F. Liu, X. G. Wang, J. H. Huang, Appl. Clay Sci., 2010, 47, 229-234.

[19] X. Li, Z. M. Zong, W. W. Ma, J. P. Cao, M. Mayyas, Z. H. Wei, Y. Li, H. L. Yan, D. Wang, R. Yang, X. Y. Wei, Fuel Process. Technol., 2015, 134,

\section{Graphical Abstract}

Chin. J. Catal., 2016, 37: 1324-1330 doi: 10.1016/S1872-2067(15)61112-3

\section{Preparation of a new solid acid and its catalytic performance in di(1-naphthyl)methane hydrocracking}

Meixia Zhao, Xianyong Wei*, Zhimin Zong

China University of Mining \& Technology

A new solid acid catalyst prepared by trifluoromethanesulfonic acid (TFMSA) impregnation into an acid-treated attapulgite (ATA) specifically hydrocracked di(1-naphthyl)methane to naphthalene and 1-methylnaphthalene over TFMSA/ATA at $300{ }^{\circ} \mathrm{C}$ in methanol without gaseous hydrogen.
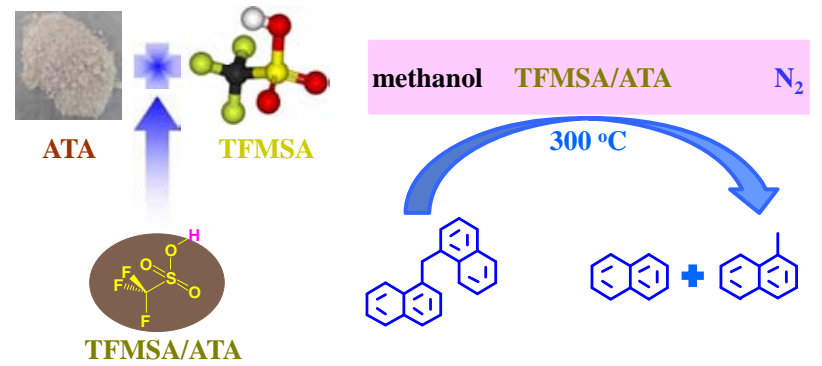
$39-45$.

[20] M. Gorsd, L. Pizzio, M. Blanco, Appl. Catal. A, 2011, 400, 91-98.

[21] A. Hess, E. Kemnitz, A. Lippitz, W. E. S. Unger, D. H. Menz, J. Catal., 1994, 148, 270-280.

[22] C. M. Kassis, J. K. Steehler, R. W. Linton, Surf. Sci. Spectra, 1994, 3, 299-306.

[23] G. E. Murch, R. J. Thorn, J. Phys. Chem. Solids, 1980, 41, 785-791.

[24] H. J. M. Bosman, A. P. Pijpers, A. W. M. A. Jaspers, J. Catal., 1996, 161, 551-559.

[25] E. Cao, R. Bryant, D. J. A. Williams, J. Colloid Interface Sci., 1996, 179, 143-150.
[26] D. F. Zhao, J. Zhou, N. Liu, Mater. Charact, 2007, 58, 249-255.

[27] J. L. Cao, G. S. Shao, Y. Wang, Y. P. Liu, Z. Y. Yuan, Catal. Commun., 2008, 9, 2555-2559.

[28] L. Rodríguez-González, F. Hermes, M. Bertmer, E. RodríguezCastellón, A. Jiménez-López, U. Simon, Appl. Catal. A, 2007, 328, 174-182.

[29] Z. H. Ni, Z. M. Zong, L. F. Zhang, S. L. Zhou, Y. C. Xiong, X. H. Wang, X. Y. Wei, Energy Fuel, 2002, 16, 1154-1159.

[30] M. Farcasiu, C. Smith, Energy Fuels, 1991, 5, 83-87.

[31] E. Ogata, X. Y. Wei, K. Horie, A. Nishijima, I. Saito, K. Ukegawa, Catal. Today, 1998, 43, 161-169.

\title{
一种新型固体酸的制备及其在二(1-萗)甲烷加氢裂解中的催化性能
}

\author{
赵美霞，魏贤勇，宗志敏 \\ 中国矿业大学煤炭加工与高效洁净利用教育部重点实验室, 江苏徐州221116
}

摘要: 煤直接液化制取轻质燃料油和重要化学品是实现煤炭资源高效洁净利用的有效途径. 煤液化的关键是在适当的温 度、氢压、溶剂和催化剂存在的条件下, 通过加氢裂解反应使连接煤中有机质大分子结构单元的较弱的桥键断裂生成可作 为液体燃料的有机小分子, 经后续的精细分离得到高附加值有机化学品和制备高性能炭材料前驱体, 进而实现煤炭资源的 高效利用. 传统的煤液化工艺反应条件苛刻, 需要高温和高氢压, 导致能耗大和设备成本较高. 酸性催化剂可使煤结构中 的桥键在远低于煤热解反应的温度下断裂, 并可有效除去煤中的杂原子, 大幅提高液化油收率, 因此酸性催化剂得到许多 研究者关注. 液体酸, 如三氟甲磺酸、氟嗍酸以及金属卤化物熔盐等均相酸性催化剂是煤液化工艺中常用的催化剂. 虽然 这些催化剂具有催化效率高和不易失活等优点, 但大多数均相催化剂难以回收和再生, 生产成本高, 设备腐蚀性大, 环境污 染严重, 因此在实际应用中受到限制.

固体酸是具有广泛工业应用前景的环境友好催化剂, 因而对固体酸的研究具有重要意义. 本研究将液体三氟甲磺酸 (TFMSA) 通过浸渍吸附法负载到酸化的凹凸棒土 (ATA) 上制备了一种新型固体酸催化剂 TFMSA/ATA, 并在相同条件下 制备了 TFMSA $/ \gamma-\mathrm{Al}_{2} \mathrm{O}_{3}$ 和 TFMSA/ZSM-5 作为对比. 对TFMSA/ATA 进行了透射电镜、傅里叶变换红外光谱、X射线光电 子能谱、X射线衍射、 $\mathrm{N}_{2}$ 吸附 以及 $\mathrm{NH}_{3}$ 程序升温脱附表征. 结果表明, TFMSA 有效负载于 ATA 载体表面及孔隙中, 未发 现明显的团聚, 载体与活性组分之间存在较强的相互作用; 另外, TFMSA/ATA 上出现超强酸位点, 说明 TFMSA/ATA 具 有超强酸性.

以二(1-菜)甲烷加氢裂解作为探针反应考察了 TFMSA/ATA 对 $\mathrm{C}_{\mathrm{ar}}-\mathrm{C}_{\mathrm{alk}}$ 桥键断裂的催化活性. 结果表明, 二(1-萫)甲烷 在 $\mathrm{N}_{2}$ 气氛和甲醇溶剂中选择性地加氢裂解, 仅得到菜和1-甲基菜, 未检测到加氢产物, 且产物䒺的收率明显高于1-甲基菜 的收率, 说明 TFMSA/ATA 对二(1-菜)甲烷选择性加氢裂解和由此产生的1-甲基菜脱甲基反应有显著的促进作用. 在相同 反应条件下, TFMSA/ATA 的活性明显高于 TFMSA $/ \gamma-\mathrm{Al}_{2} \mathrm{O}_{3}$ 和 TFMSA/ZSM-5, 这是由于 TFMSA/ATA 较大的比表面积以 及载体 ATA 与活性组分 TFMSA 之间存在较强的相互作用有利于催化剂释放质子. 由催化剂释放的质子优先进攻二(1菜)甲烷中的取代位导致 $\mathrm{C}_{\mathrm{ar}}-\mathrm{C}_{\mathrm{alk}}$ 键断裂是二(1-荎)甲烷加氢裂解的关键步骤. 催化剂循环实验表明, TFMSA/ATA 在循环 使用 4 次后仍具有较高的催化活性, 使用后催化剂酸性没有明显降低, 说明 TFMSA/ATA 具有良好的稳定性.

关键词: 固体酸; 二(1-荎)甲烷; 加氢裂解; $\mathrm{H}^{+}$转移

收稿日期: 2016-03-03. 接受日期: 2016-04-15. 出版日期: 2016-08-05.

*通讯联系人. 电话: (0516)83885951; 传真: (0516)83884399; 电子信箱: wei_xianyong@163.com 基金来源：中国矿业大学中央高校基本科研业务费专项资金 (2014ZDPY34); 江苏高校优势学科建设工程资助项目. 本文的英文电子版由Elsevier出版社在ScienceDirect上出版(http://www.sciencedirect.com/science/journal/18722067). 